\title{
Improving detection of foraminifera by cathodoluminescence
}

\author{
Bogusław Kołodziej • Agata Jurkowska • \\ Michał Banaś • Daria Ivanova
}

Received: 1 July 2010/Accepted: 21 December 2010/Published online: 9 February 2011

(C) The Author(s) 2011. This article is published with open access at Springerlink.com

\begin{abstract}
Cathodoluminescence (CL) studies of LowerMiddle Oxfordian marls and limestones, as well as clasts from the uppermost Turonian-?Early Coniacian conglomerates of the Cracow Upland (southern Poland), reveal that the $\mathrm{CL}$ view of foraminifers from some lithologies differs from that in transmitted light. In particular, the CL technique revealed abundant tests of planktonic species Globuligerina oxfordiana in the Middle Oxfordian glauconitic marls, which under transmitted light are either poorly visible or remain completely undetected. Bright red-orange luminescence characterizes originally hyaline aragonitic tests of G. oxfordiana, but also several calcitic benthic species, in spite of their different taxonomic position and original test structure and mineralogy. In sponge microbial boundstones, foraminifers generally do not show the CL emission, or show a weak luminescence. Similarly, Late Cretaceous foraminifera represented mostly by planktonic taxa were detected or their view was clearly improved under CL only in some clasts from the uppermost Turonian-?Early Coniacian conglomerates filling karstic cavities. In other clasts, foraminifera are clearly visible only under normal transmitted light, therefore the luminescence signature is highly spatially variable. These results indicate
\end{abstract}

B. Kołodziej $(\varangle) \cdot$ A. Jurkowska

Institute of Geological Sciences, Jagiellonian University, Oleandry 2a Str., 30-063 Kraków, Poland

e-mail: boguslaw.kolodziej@uj.edu.pl

M. Banaś

Institute of Geological Sciences, Polish Academy of Sciences, Senacka 3 Str., 31-002 Kraków, Poland

D. Ivanova

Geological Institute, Bulgarian Academy of Sciences,

Acad. G. Bonchev Str., B1. 24, 1113 Sofia, Bulgaria a strong influence of lithology and diagenesis and rather minor effects of shell structure on luminescence of microfossils. The CL technique can be a useful tool in the detection and documentation of abundance patterns of foraminifers that are poorly preserved under transmitted light.

Keywords Cathodoluminescence microscopy . Foraminifera - Oxfordian · Late Cretaceous . Cracow Upland · Southern Poland

\section{Introduction}

Cathodoluminescence or $\mathrm{CL}$ is a kind of luminescence in which longer wavelength infra-red emissions become visible by reflecting properties of the studied material. In carbonates, the main activator elements, usually incorporated during diagenesis, are $\mathrm{Mn}^{2+}$ and REEs resulting in red-orange luminescence, whereas $\mathrm{Fe}^{2+}$ is the most important quencher element. Cathodoluminescence is a significant tool in sedimentary petrology (for reviews, see Pagel et al. 2000; Richter et al. 2003).

Although this method has been successfully employed in the study of carbonate and non-carbonate fossils, it is still not widely used by palaeontologists. Outlines and internal structures of skeletal organisms, invisible in light microscope, can be enhanced under CL, which thus helps in the identification of poorly preserved fossils (e.g., Amieux 1987; Martini et al. 1987; Rittel and Stanley 1993). In order to get better insights into the preservation and variations in the abundance of foraminifers from Upper Jurassic and Upper Cretaceous deposits, the present study applies the simple cold CL technique. More complex techniques, including CL spectral analysis and high 
sensitivity (hot CL), can provide more detailed data on biomineralization, skeletal microstructures, environmental parameters and diagenetic history (e.g., Barbin et al. 1991, 1995; Barbin 2000; Kershaw 1994; Tomašových and Farkas 2005; England et al. 2006).

The objectives of the present paper are twofold: (1) to test whether cathodoluminescence affects the detectability of foraminifers in the Oxfordian and the uppermost Turonian-?Lower Coniacian deposits of the Kraków region, and (2) to encourage the application of this technique in foraminiferal studies.

\section{Material and geological context}

The studied material was derived from Oxfordian and the uppermost Turonian-?Lower Coniacian sediments of the Kraków (Cracow) Upland, which is a southern part of the Polish Jura Chain. The studied area is characterized by horsts and grabens resulting from Miocene tectonic activity at the front of the Outer Carpathians thrust.

Oxfordian limestones and marls, including well-exposed sponge-microbial buildups, were formed on the northern Tethyan shelf. They usually cover Callovian siliciclastic rocks, marls and limestones. The oldest Oxfordian rocks are developed as marls and marly limestones. MiddleUpper Oxfordian facies are dominated by bedded limestones and sponge-microbial bioherms (e.g., Dżułyński 1952; Matyszkiewicz 1997; Matyja 2006). Foraminifera from Oxfordian rocks from the Cracow Upland have been the subject of a few studies (Olszewska and Wieczorek 1988; Barwicz-Piskorz 1989). Localities (Podłęże, Młynka, Zalas) selected for this study expose Early-Middle Oxfordian marls and limestones (Fig. 1).

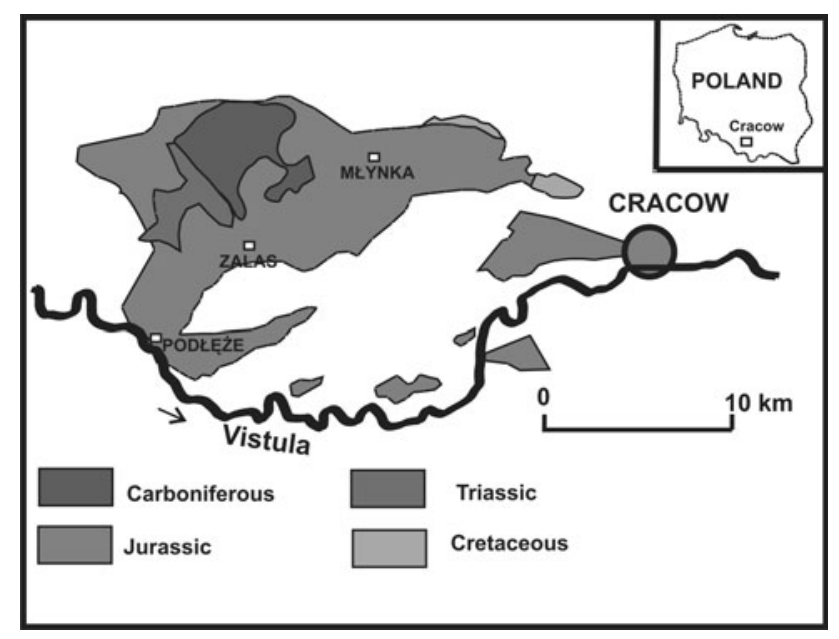

Fig. 1 General geographic and geological position of the studied localities. Simplified geology based on Gradziński (1993)
Podłęże The studied foraminifera from Podłęże come from a 40-cm-thick interval of Middle Oxfordian (Plicatilis Zone) glauconitic marls that have recently been poorly exposed. Thin sections were made mainly from sediment filling ammonite shells that had been collected and studied by Hoffmann (1983).

Młynka (inactive quarry) The Lower Oxfordian interval (Cordatum Zone) is represented by grey marls with abundant ammonites, as well as by marls and marly limestones with sponges. The Middle Oxfordian is developed as peloidal platy and mid- and thick bedded wackestone limestones (Plicatilis Zone), covered by sponge-microbial bioherms and related detritical limestones (Transversarium Zone) (Hoffmann and Matyszkiewicz 1989; for detailed biostratigraphy, see Głowniak 2006; Głowniak and Matyja 2006). In the upper part of the bedded platy limestones, a thin horizon of glauconitic marls has been recognized (Jurkowska 2008).

Zalas quarry In a well-known Jurassic section in the Zalas quarry, Oxfordian strata lie above Callovian siliciclastic and carbonates sediments or locally even directly on Permian rhyodacites. Callovian-Oxfordian deposits have been the subject of sedimentological and palaeontological papers, most of which were focused on biostratigraphy (e.g., Dżułyński 1952; Giżejewska and Wieczorek 1977; Matyja and Tarkowski 1981; Matyja 2006). The Lower Oxfordian interval (up to $2 \mathrm{~m}$ thick) is condensed and consists of marls representing the Mariae Zone and the Cordatum Zone. Above this, occurs a complex of spongemicrobial bioherms interbedded with thin-bedded limestones and marls (ca. $10 \mathrm{~m}$ ) representing the Middle Oxfordian Plicatilis Zone (Giżejewska and Wieczorek 1977; Matyja and Tarkowski 1981; Matyja 2006).

The Late Cretaceous foraminifers we studied come from carbonate clasts within conglomerate filling karstic cavities developed on the surface of an abrasion platform cutting Oxfordian limestones in Cracow (Fig. 1). They were exposed in temporary building pits at the Pychowicka Street, Zakrzówek Horst. Preliminary studies of the carbonate clasts (mostly foraminiferal-calcisphere wackestone) and matrix within these conglomerates revealed foraminifers and nannoplankton indicating the latest $\mathrm{Tu}$ ronian-?Early Coniacian age (Kołodziej et al. 2010). In Cracow, Upper Cretaceous sediments are preserved as discontinuous cover (up to $25 \mathrm{~m}$ thick). The Coniacian stage used to be considered to be absent or not documented palaeontologically, although it was recognized ca. $30 \mathrm{~km}$ north of Cracow (Walaszczyk 1992; Olszewska-Nejbert and Świerczewska-Gładysz 2009). In the section studied, Santonian sediments are absent; Campanian marls and limestones, with abundant well-preserved, mostly planktonic 
foraminifera, occur directly above Oxfordian strata or fill injection dykes within the Oxfordian basement (Kołodziej et al. 2010).

\section{Methods}

$\mathrm{CL}$ analyses were carried out on polished, uncovered thin sections with a Carl Zeiss Jena Long Distance petrographical microscope (JENAPOL $1.4 / \times 10$ ) with a Cambridge Image Technology (CITL) 8,300 Mk III cold cathode instrument (Institute of Geological Sciences, Polish Academy of Sciences, Cracow). This equipment operated at a beam voltage of $15-20 \mathrm{kV}$ and current of 400-500 mA. All figures were performed under comparable exposure times. Around 20 thin sections from the Oxfordian and six from the uppermost Turonian-?Lower Coniacian rocks were observed under CL.

In the present study, only polished thin sections were analysed. CL studies of polished thin sections give better results for studies of small-scale skeletal structures in comparison with unpolished thin sections (Rittel and Stanley 1993).

\section{Results}

Observations of foraminifers from some Oxfordian and the uppermost Turonian-?Lower Coniacian deposits reveal that their CL view is radically different to that in light microscope view. CL observations of the Middle Oxfordian glauconitic marls show that foraminifers are abundant (Fig. 2b, d, f, i, k). When thin sections are observed in transmitted light, foraminifers are poorly visible or even indistinguishable (Fig. 2a, c, e, h, j), whereas they show bright red-orange luminescence under CL. Foraminiferal assemblages are pauspecific, consisting mainly of abundant planktonic species, possibly Globuligerina oxfordiana (Grigelis) (see also Olszewska and Wieczorek 1988; Barwicz-Piskorz 1989), although random test sections do not allow for precise determination of all specimens. The morphotypes are equivalent to medium and large forms of G. oxfordiana (Grigelis) according to the classification of Wernli and Görög (2000). Other determined foraminifers recognized in thin sections are rare. Benthic species, Nodosaria sp. and Lenticulina sp. (Fig. 2g, i), show similar luminescence as $G$. oxfordiana. Undetermined benthic foraminifers with tests of dark, "micritic" appearance show poor luminescence, and they are much more visible in transmitted light.

Associated fossils observed in thin section include ammonite shells (Fig. 2f) and sponge spicules (Fig. 2d) show bright red-orange luminescence. The fossils are clearly visible within micritic matrix, which is weakly luminescent. The matrix, composed of microsparite or sparite, is luminescent, but foraminifers are still visible under CL (Fig. 2i). Green-brown grains of glauconite occur commonly within the chambers of foraminiferal tests. Glauconite is non-luminescent (Fig. 2b, d).

The Middle Oxfordian peloidal wackestones (Fig. 3a, b) and sponge-microbial boundstones (Fig. 3c, d) from Młynka contain rare hyaline foraminiferal tests which are dull in CL view, and thus are less distinguishable than under normal transmitted light. Matrix has usually bright red-orange luminescence. In the Lower Oxfordian grey marls (Młynka), rare planktonic foraminifers are more clearly recognizable under $\mathrm{CL}$ and have red-orange luminescence (Fig. 2j, k).

Observations of foraminifera from the Late Cretaceous succession at Cracow revealed that CL was a useful tool only in the case of some carbonate clasts from the uppermost Turonian-?Lower Coniacian conglomerate. In most clasts, foraminifera are well preserved and distinguishable under normal transmitted light. In three studied clasts, foraminifera were revealed or their view was enhanced only under CL. Red-orange luminescence is exhibited by planktonic foraminifera which dominate in those limestones (Fig. 4a, b), as well as by benthic taxa: ?Gaudryina sp. and ?Stensioeina sp. (Fig. 4c, d). However, we emphasize that foraminifera show different states of preservation even within the same clast. Diagenetic changes within conglomerate vary, and the boundaries between carbonate clasts and carbonate matrix are mostly poorly marked. Therefore, the evaluation of the $\mathrm{CL}$ view of foraminifera from particular clasts and matrix would be difficult.

\section{Discussion}

These comparative analyses of thin sections in normal transmitted light and in CL demonstrate the utility of this technique in distinguishing the preservation and abundance patterns of foraminifers occurring in some facies types.

CL studies were particularly useful in the detection of and improving the view of foraminifera that occur in Oxfordian glauconitic marls. Foraminifers show bright redorange, while glauconite which commonly fills foraminiferal test chambers is non-luminescent (cf. Banner et al. 1988). The high abundance of planktonic foraminifera is a result of stratigraphic and sedimentological condensation typical of the Lower Oxfordian deposits, and locally also of the Middle Oxfordian deposits of the Cracow region (Giżejewska and Wieczorek 1977; Hoffmann 1983; Matyja and Tarkowski 1981; Olszewska and Wieczorek 1988). 

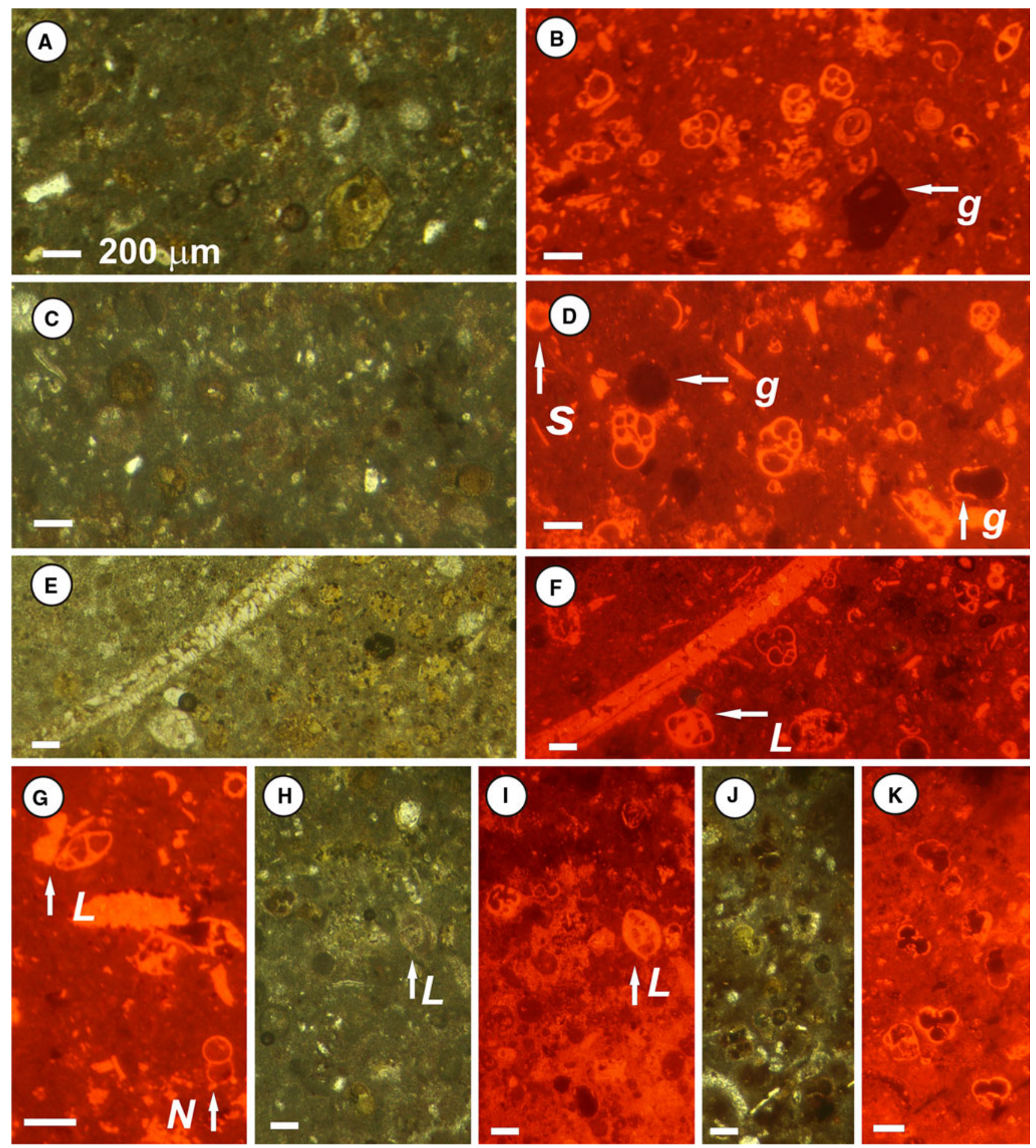

Fig. 2 Thin section photomicrographs of the Middle Oxfordian glauconitic marls under transmitted light $(\mathbf{a}, \mathbf{c}, \mathbf{e}, \mathbf{h}, \mathbf{j})$ and under cathodoluminescence $(\mathbf{b}, \mathbf{d}, \mathbf{f}, \mathbf{g}, \mathbf{i}, \mathbf{k})$. Most foraminifera are attributed to Globuligerina oxfordiana. a-d Arrows $(\mathrm{g}$ ) indicates large grains of

According to Olszewska and Wieczorek (1988), planktonic foraminifera (washed material) from the Lower Oxfordian glauconitic condensed sediments in the Cracow region are preserved mostly as glauconitic casts. glauconite (on c, d, glauconite fills foraminiferal chambers). c, d Sponge spicule $(s)$. e, f Fragment of ammonite shell. f, g, i Other foraminifera: Lenticulina sp. $(L)$, Nodosaria sp. $(N)$. a-i Podłęże; j, k Młynka. All scale bars $200 \mu \mathrm{m}$

Planktonic G. oxfordiana, as well as benthic Nodosaria sp and Lenticulina sp., show similar luminescence despite their different taxonomic position and original test structure. According to Wernli and Görög (2007), the genus 

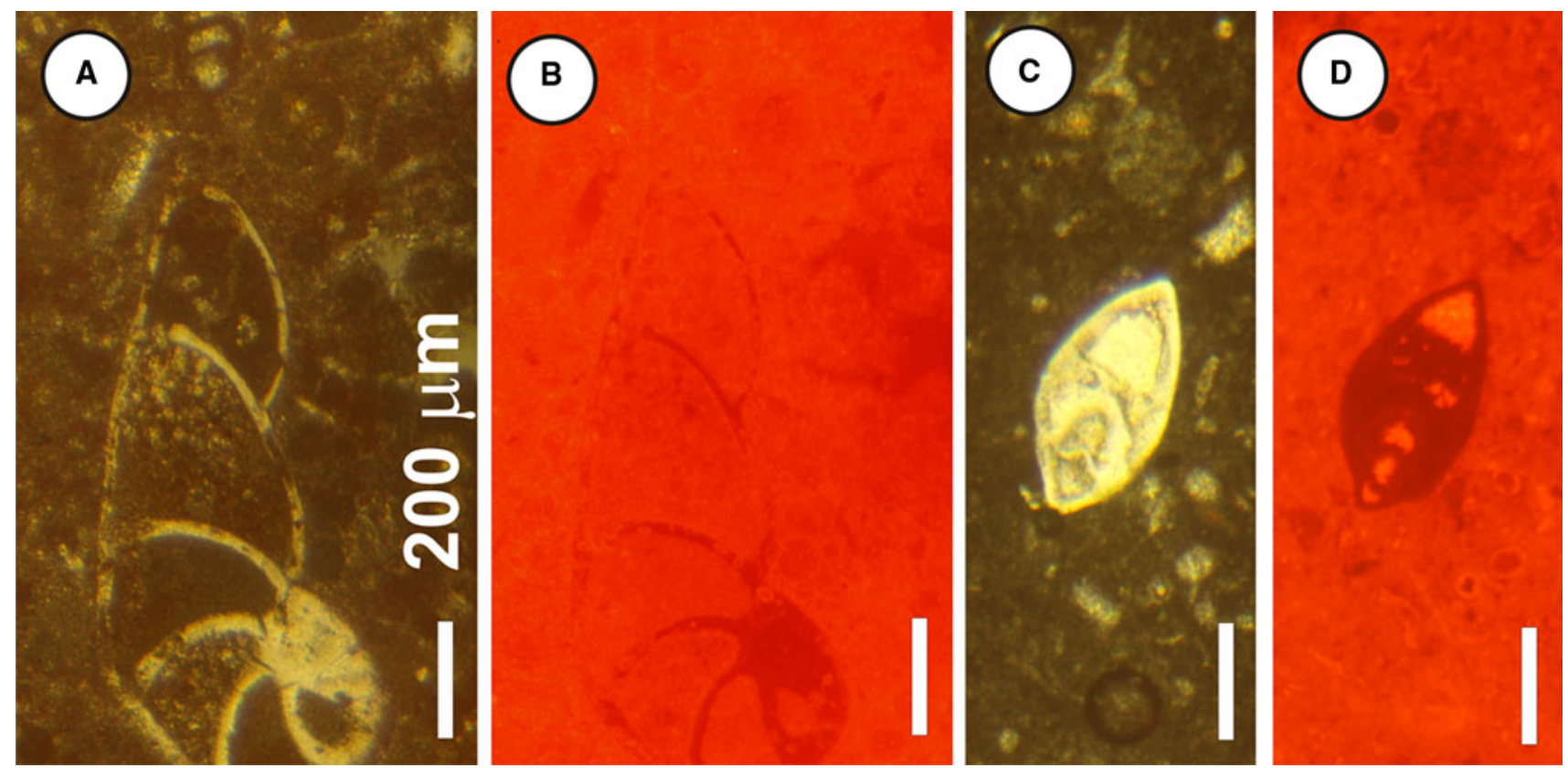

Fig. 3 a-b Astacolus sp. from the Middle Oxfordian peloidal wackestone (platy limestones) under normal light (a) and CL (b). c, d Lenticulina sp. from the Middle Oxfordian sponge-microbial

boudstones (Młynka) under normal light (c) and under CL (d). a-d Młynka. All scale bars $200 \mu \mathrm{m}$

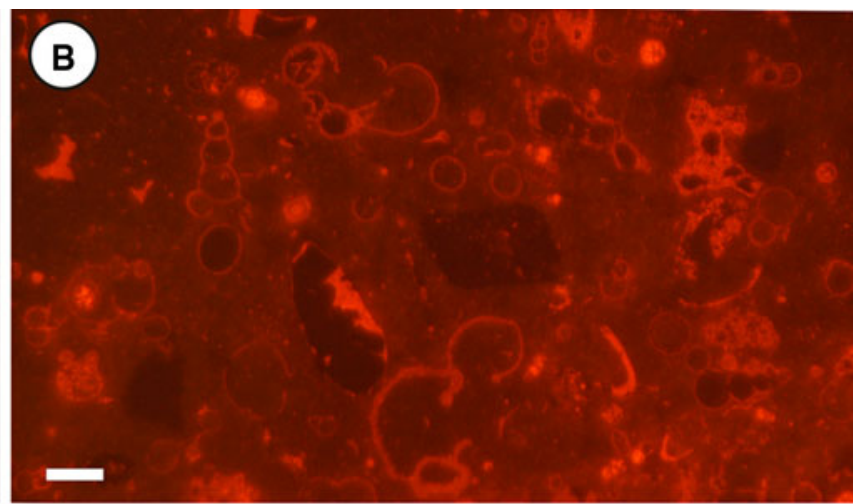

\section{$100 \mu \mathrm{m}$}
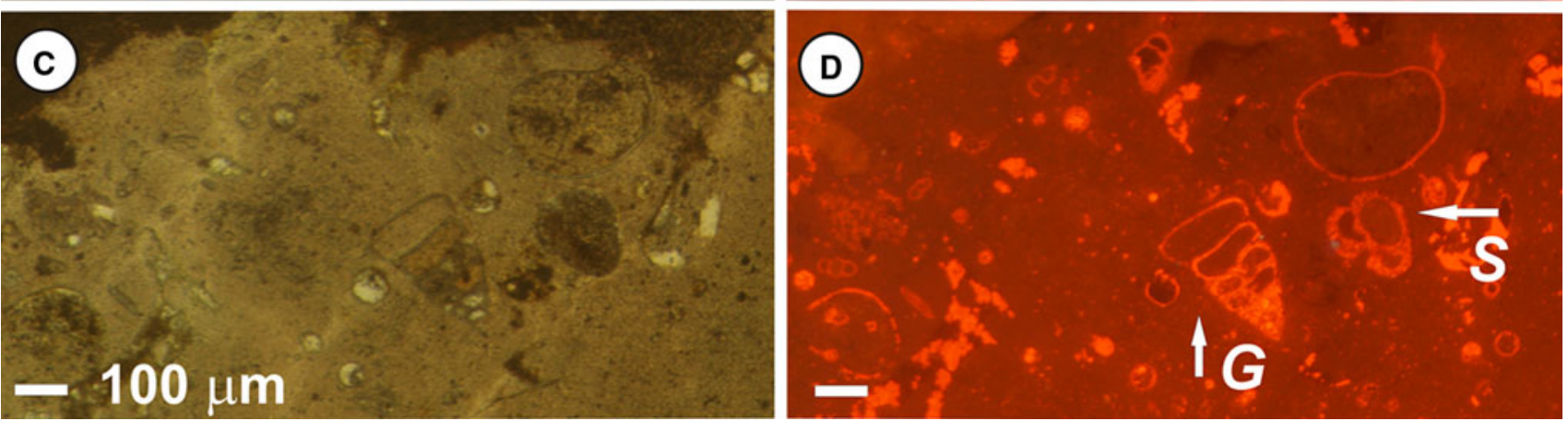

Fig. 4 Thin section photomicrographs of foraminifera from the uppermost Turonian-?Lower Coniacian conglomerate under transmitted light (a, c) and CL $(\mathbf{b}, \mathbf{d})$. a, b Abundant planktonic foraminifera. c, d Benthic foraminifera ?Gaudryina sp. $(G)$ and ?Stensioeina sp. (S). Kraków

Globuligerina belongs to the suborder Globigerinina, superfamily Favusellacea, family Conoglobigerinidae. G. oxfordiana had hyaline, radial, finely perforate calcareous walls, almost certainly aragonitic (Loeblich and Tappan 1987; Wernli and Görög 2000; Görög and Wernli 2003). Benthic foraminifers Nodosaria sp. (suborder 
Lagenina, family Nodosaridae) and Lenticulina sp. (suborder Lagenina, family Vaginulinidae) had calcareous walls, perforate, radial in structure, and of possibly calcite and low-Mg calcite composition, respectively (Loeblich and Tappan 1987). Benthic foraminifers (Astacolus sp., Nodosaria sp., Lenticulina sp.) and rare planktonic foraminifers from the Middle Oxfordian peloidal wackestones and sponge-microbial boundstones (Młynka), in contrast to foraminifers from glauconitic marls, are dull in CL view. Only rare planktonic foraminifers from the Lower Oxfordian grey marls (Młynka) are better defined under CL.

Late Cretaceous foraminifera showing luminescence in our samples represent mostly planktonic taxa (Globigerinina), and rare benthic forms: ?Gaudryina sp. (suborder Verneuilinina, family Reophacellidae), and ?Stensioeina sp. (Rotaliina, Gavelinellidae). Gaudryina possessed agglutinated calcareous, solid, and non-canaliculate test, and Stensioeina possessed calcareous, optically granular, and coarsely perforate test.

Although luminescence of skeletal elements commonly indicates diagenetic alteration, it is known that Holocene skeletal remains unaffected by diagenesis often reveal luminescence. No studied modern calcite planktonic foraminifera do show luminescence under CL, but almost all benthic porcelanous foraminifera show an orange emission. Recent aragonitic foraminifera are rare and have weak greenish luminescence (Barbin 2000). The luminescence intensity of Recent foraminifera from a given site is generally similar, but does show variation among samples from different environments and regions. Manganese content in foraminiferal tests can be linked with environmental parameters or ontogeny (growth rate). Further luminescence studies are necessary for foraminifera which have unequivocally died recently (Barbin et al. 1991).

The poorly diverse assemblage of foraminifers identified in thin sections does not allow for the detailed analysis of the influence of original mineralogy and microstructure of tests versus diagenetic processes and their present luminescence. However, it seems that the primary control on CL luminescence is represented by the diagenetic history of the foraminifera-bearing sediments because taxa with the same test mineralogy differ in their luminescence among facies types.

Our data indicate that the lack or presence of luminescence is unrelated to original test structure, but rather is controlled by lithology and diagenesis, being a consequence of differences in the concentration of $\mathrm{Mn}^{2+}$ or other activator elements. Evidence for diagenetic overprint of the Oxfordian samples is supported by other diagenetic features of the host sediments, including compaction, lithification, and luminescence of carbonate matrix and cement, and by the differential preservation of ammonites. For example, only ammonites from glauconitic marls possess a neomorphic shell, whereas those from other facies are preserved as external moulds or inner moulds with shells preserved as void-filling calcite cements (Jurkowska 2008).

Differences in CL response of the studied Late Cretaceous foraminifera are likely to be linked with diagenetic processes after deposition of conglomerate within karstic cavities. This is suggested by variations in preservation within the particular clast.

A review of the literature revealed only two case studies with spectacular CL views of fossil foraminifera. Martini et al. (1987) analysed Triassic foraminifers from southwest Sardinia (Italy). Although in normal light foraminifers seemed to be completely lost by recrystallisation, CL observations showed an abundant monospecific assemblage of Agathammina? sp. similar to Agathammina? inconstans (Michalik, Jendrejakova and Borza). Amieux (1987) studied foraminifers from Middle Triassic packstone limestones from Basilicate (Campania-Lucania Apennines, southern Italy). Test details of Ophthalmidium sp. obliterated under transmitted light were enhanced under CL.

\section{Conclusions}

Observations of thin sections of Lower and Middle Oxfordian marls and limestones and carbonate clasts from the uppermost Turonian-?Lower Coniacian conglomerates reveal that the CL view of foraminifers from some facies is radically different compared with the view under a light microscope. CL studies are particularly useful in the identification of foraminifera from Oxfordian glauconitic marls, which under transmitted light were poorly preserved or overprinted by diagenesis. When observed in a CL microscope, tests of planktonic Globuligerina oxfordiana are abundant and show bright red-orange luminescence. Only in some clasts within Late Cretaceous conglomerate were foraminifera detected under CL, or their morphology clearly enhanced. Luminescence of rare benthic forms both from Oxfordian and the uppermost Turonian-?Lower Coniacian is similar to planktonic forms, despite their different taxonomic position and original test structure and mineralogy. However, undetermined Oxfordian benthic foraminifers with tests of dark, "micritic" appearance show poor luminescence implying some effects of shell structure on CL intensity. In contrast, CL studies were not practicable for Oxfordian peloidal wackestones and sponge-microbial boundstones, or for most observed Upper Cretaceous foraminifera, because they are much more visible in transmitted light. These data indicate that in our material luminescence is primarily controlled by the lithology and diagenesis of the host sediment.

These and previous results (Amieux 1987; Martini et al. 1987) indicate the usefulness of cathodoluminescence in 
studies of foraminifera from rocks with different depositional and diagenetic histories, particularly when they can only be studied in thin sections. If the CL response of cement or host sediment strongly contrasts the skeleton material under CL, this technique can also be a useful tool in the better documentation of the studied fossils.

Acknowledgments We thank Dr. Adam Tomašových (Chicago) and an anonymous reviewer for valuable comments and critical remarks on the manuscript, and Dr. Stephen Vincent (Cambridge) for linguistic help.

Open Access This article is distributed under the terms of the Creative Commons Attribution Noncommercial License which permits any noncommercial use, distribution, and reproduction in any medium, provided the original author(s) and source are credited.

\section{References}

Amieux P (1987) Description pétrographique de foraminifères par combinaison d'images en lumière naturelle et en cathodoluminescence. C R Acad Sci Paris (II) 304:741-744

Banner JL, Hanson GN, Meyers WJ (1988) Determination of initial Sr isotopic compositions of dolostones from the Burlington-Keokuk Formation (Mississippian); constraints from cathodoluminescence, glauconite paragenesis and analytical methods. J Sediment Res 58:673-687

Barbin V (2000) Cathodoluminescence of carbonate shells: biochemical vs diagenetic process. In: Pagel $\mathrm{M}$, Barbin V, Blanc P, Ohnenstetter D (eds) Cathodoluminescence in geosciences. Springer, Berlin, pp 303-329

Barbin V, Ramseyer K, Debenay JP, Schein E, Roux M, Decrouez D (1991) Cathodoluminescence of Recent biogenic carbonates: an environmental and ontogenetic fingerprint. Geol Mag 128:19-26

Barbin V, Brand U, Hewitt RA, Ramseyer K (1995) Similarity in cephalopod shell biogeochemistry since Carboniferous: evidence from cathodoluminescence. Geobios 28:701-710. doi: 10.1016/373S0016-6995(95)80064-6

Barwicz-Piskorz W (1989) Microfauna of Lower Malm deposits at Zalas, South Poland. Kwart AGH Geologia 15:6-27 (in Polish with English summary)

Dżułyński S (1952) The origin of the Upper Jurassic limestones in the Cracow area. Rocz Pol Tow Geol 21:125-180 (in Polish with English summary)

England J, Cusack M, Paterson NW, Edwards P, Lee M, Martin R (2006) Hyperspectral cathodoluminescence imaging of modern and fossil carbonate shells. J Geophys Res 111(G03001):1-8. doi: $10.1029 / 2005 J G 000144$

Giżejewska M, Wieczorek J (1977) Remarks on the Callovian and Lower Oxfordian of the Zalas area (Cracow Upland, Southern Poland). Bull Acad Pol Sci Sér Sci Terre 24:167-175

Głowniak E (2006) The Platysphinctes immigration event: biostratigraphic and palaeoblogeographic implications for the Middle Oxfordian (Late Jurassic) seas of Central Europe (NW Germany and Poland). N Jb Geol Paläont Abh 241:155-201

Głowniak E, Matyja BA (2006) Młynka Quarry. Lower to lower Middle Oxfordian. In: Wierzbowski A, Aubrecht R, Golonka J, Gutowski J, Krobicki M, Matyja BA, Pieńkowski G, Uchman A (eds) Jurassic of Poland and adjacent Slovakian Carpathians. Field trip Guidebook of 7 th international congress on the Jurassic system. Kraków, 6-18 Sept 2006, pp 138-141
Görög A, Wernli R (2003) Palaeobiogeography of the Middle Jurassic protoglobigerinids (Foraminifera) in thin sections. Eclog Geol Helvet 96:237-248

Gradziński R (1993) Geological map of Cracow region without Quaternary and terrestrial Tertiary deposits. Muzeum Geologiczne, Instytut Nauk Geologicznych PAN, Kraków

Hoffmann M (1983) Stratygrafia jury okolic Mirowa i Podłęża. M.Sc. thesis, Jagiellonian University, Kraków (in Polish)

Hoffmann M, Matyszkiewicz J (1989) Wykształcenie litologiczne i sedymentacja osadów jury w kamieniołomie Młynka. In: Rutkowski J (ed) Przewodnik LX Zjazdu Polskiego Towarzystwa Geologicznego, Kraków14-16 września 1989, pp 78-83 (in Polish)

Jurkowska A (2008) Tafonomia i paleoekologia amonitów z osadów oksfordu okolic Krakowa. M.Sc. Thesis, Jagiellonian University, Kraków (in Polish)

Kershaw S (1994) Cathodoluminescence of Silurian stromatoporoids from Gotland, Sweden. Cour Forsch Inst Senckenberg 172:307-318

Kołodziej B, Szulc J, Machaniec M, Kędzierski M, Duda M (2010) Injection dykes as evidence of Campanian synsedimentary tectonics on the Cracow Swell, southern Poland. Ann Soc Geol Polon 80:285-301

Loeblich AR, Tappan H (1987) Foraminiferal Genera and their classification. Van Nostrand Reinhold, New York

Martini R, Amieux P, Gandin A, Zaninetti L (1987) Triassic foraminifers from Punta Tonnara (SW Sardinia) observed in cathodoluminescence. Rev Paléobiol 6:3-27

Matyja BA (2006) Stop A17-Zalas Quarry-Callovian transgressive to condensed pelagic deposits, Lower to lowermost Middle Oxfordian deposits of sponge megafacies. In: Wierzbowski A, Aubrecht R, Golonka J, Gutowski J, Krobicki M, Matyja BA, Pieńkowski G, Uchman A (eds) Jurassic of Poland and adjacent Slovakian Carpathians. Field trip guidebook of 7 th international congress on the Jurassic system, Kraków, 6-18 Sept 2006, pp 70-72

Matyja BA, Tarkowski R (1981) Lower and Middle Oxfordian ammonite biostratigraphy at Zalas in the Cracow Upland. Acta Geol Pol 31:1-14

Matyszkiewicz J (1997) Microfacies, sedimentation and some aspects of diagenesis of Upper Jurassic sediments from the elevated part of the Northern peri-Tethyan Shelf: a comparative study on the Lochen area (Schwäbische Alb) and the Cracow area (CracowWieluń Upland, Poland). Berlin Geowiss Abh E 21:1-111

Olszewska B, Wieczorek J (1988) Callovian-Oxfordian foraminifera of the northern Tethyan shelf: an example from the Cracow Upland (Southern Poland). Rev Paléobiol Spec Vol 2:191-196

Olszewska-Nejbert D, Świerczewska-Gładysz E (2009) The phosphatized sponges from the Santonian (Upper Cretaceous) of the Wielkanoc Quarry (southern Poland) as a tool in stratigraphical and environmental studies. Acta Geol Pol 59:483-504

Pagel M, Barbin V, Blanc P, Ohnenstetter D (eds) (2000) Cathodoluminescence in geosciences. Springer, Berlin

Richter DK, Götte T, Götze J, Neuser RD (2003) Progress in application of cathodoluminescence (CL) in sedimentary petrology. Miner Petrol 79:127-166. doi:10.1007/s00710-003-0237-4

Rittel JF, Stanley GD Jr (1993) Enhanced skeletal details and diagenetic processes of Triassic corals revealed by cathodoluminescence. Cour Forsch Inst Sencken 164:339-346

Tomašových A, Farkas J (2005) Cathodoluminescence of Late Triassic terebratulid brachiopods: implications for growth patterns. Palaeogeogr Palaeoclimatol Palaeoecol 216:215-233. doi: 10.1016/j.palaeo.2006.06.028 
Walaszczyk I (1992) Turonian through Santonian deposits of the Central Polish Uplands; their facies development, inoceramid paleontology and stratigraphy. Acta Geol Pol 42:1-122

Wernli R, Görög A (2000) Determination of Bajocian protoglobigerinids of Gyenespuszta (Bakony Mts., Hungary). Rev Paléobiol 19:399-407
Wernli R, Görög A (2007) Protoglobigerines et Oberhauserellidae (Foraminiferes) du Bajocien-Bathonien du Jura meridional, France. Rev Micropal 50:185-205 